\title{
Phosphate import in plants: focus on the PHT1 transporters
}

\author{
Laurent Nussaume ${ }^{1}$, , Satomi Kanno ${ }^{2}$, Hélène Javot ${ }^{1}$, Elena Marin ${ }^{1}$, Nathalie Pochon ${ }^{1}$, Amal Ayadi $^{1}$, \\ Tomoko M. Nakanishi ${ }^{2}$ and Marie-Christine Thibaud ${ }^{1}$ \\ IBEB-SBVME Laboratoire de Biologie du Développement des Plantes, UMR6191 CNRS-Commissariat à l'Energie Atomique et aux Energies Alternatives \\ Cadarache, Université Aix-Marseille, F-13108 Saint-Paul-lez-Durance, France \\ ${ }^{2}$ Graduate School of Agricultural and Life Sciences, The University of Tokyo, 1-1-1, Yayoi, Bunkyo-ku, Tokyo, Japan 113-8657
}

\author{
Edited by: \\ Angus S. Murphy, Purdue University, \\ USA

\section{Reviewed by:} \\ Bronwyn Jane Barkla, Universidad \\ Nacional Autónoma de México, \\ Mexico \\ Joshua Blakeslee, The Ohio State \\ University, USA \\ ${ }^{*}$ Correspondence: \\ Laurent Nussaume, IBEB-SBVME \\ Laboratoire de Biologie du \\ Développement des Plantes, UMR \\ 6191 CNRS-Commissariat à l'Energie \\ Atomique et aux Energies \\ Alternatives Cadarache, Université \\ d'Aix-Marseille, F-13108 \\ Saint-Paul-lez-Durance, Cedex, \\ France. \\ e-mail: Inussaume@cea.fr
}

The main source of phosphorus for plants is inorganic phosphate (Pi), which is characterized by its poor availability and low mobility. Uptake of this element from the soil relies heavily upon the PHT1 transporters, a specific family of plant plasma membrane proteins that were identified by homology with the yeast PHO84 Pi transporter. Since the discovery of PHT1 transporters in 1996, various studies have revealed that their function is controlled by a highly complex network of regulation. This review will summarize the current state of research on plant PHT1 multigenic families, including physiological, biochemical, molecular, cellular, and genetics studies.

Keywords: phosphate, phosphorus, plant, transporter, uptake, PHT1, transcriptional and post-translational regulation

\section{INTRODUCTION}

Phosphorus is an essential macro-element for life. It plays a key role in many crucial processes such as heredity (DNA, RNA), cellular compartmentalization (membrane lipids), energy metabolism (ATP), and phosphorylation-based signaling mechanisms (Poirier and Bucher, 2002; Vance et al., 2003; Misson et al., 2005; Jouhet et al., 2007). Despite its abundance in the environment (ranked as the 11th most abundant element), phosphorus is neither easily accessible nor evenly distributed in most soils. For example, 20$80 \%$ of phosphorus in soil can be present as organic pools (mostly composed of plant and microorganism residues), which cannot be absorbed directly by the plants (Richardson, 1994). In plants, phosphorus represents $0.1-0.5 \%$ of the dry weight, and this element is acquired in the form of phosphate [inorganic phosphate ( $\mathrm{Pi})$ ], an inorganic form of $\mathrm{P}$. Depending on the $\mathrm{pH}$, several anions can exist $\left(\mathrm{PO}_{4}^{3-}, \mathrm{HPO}_{4}^{2-}, \mathrm{H}_{2} \mathrm{PO}_{4}^{-}\right.$), however between $\mathrm{pH}$ 5-6 the predominant form is dihydrogen phosphate ion $\left(\mathrm{H}_{2} \mathrm{PO}_{4}^{-}\right)$. Analysis of Pi uptake indicates that this latter form is favored for transport into the plants, since maximum Pi uptake is typically observed within this $\mathrm{pH}$ range (Ullrich-Eberius et al., 1984; Furihata et al., 1992; Schachtman et al., 1998). Two factors restrict the availability of this anion in soil: (i) its assimilation by microbes and (ii) its capacity to strongly interact with most of the cations. In acidic soils ( $30 \%$ of soils worldwide), aluminum and iron are abundant and often combined with Pi. This interaction can strongly limit their bioavailability for biological processes (Von Vexhull and Mutert, 1998). Conversely, in vitro experiments have demonstrated that a high Pi level can reduce the pool of some metals in Arabidopsis, by a factor of 4-5 (Hirsch et al., 2006). The importance of Pi chelation by cations or organic compounds is apparent, when juxtaposed against the poor efficiency of phosphate fertilizers, where up to $80 \%$ of provided Pi cannot be acquired by the crops. Furthermore, $\mathrm{Pi}$ is poorly mobile in the soil, as its diffusion coefficient is very low (from $10^{-12}$ to $10^{-15} \mathrm{~m}^{2} \mathrm{~s}^{-1}$ ). As a consequence, Pi uptake by the plant creates a depleted area around the roots (Ullrich-Eberius et al., 1984; Furihata et al., 1992; Schachtman et al., 1998). Therefore, Pi can easily be considered as one of the least available plant macronutrients (Raghothama, 1999).

Before the modern intensification of agriculture, farmers relied mostly on phosphorus naturally present in soils or from manure. However, as a growing world population has put high demands on food production (with adverse effects on soil degradation), agriculture has become dependent on external sources of phosphate fertilizers (such as guano, ground bones, and phosphate rock) to increase crop yields (Cordell et al., 2009). Phosphate rock is an abundant and cheap source of phosphorus, and has quickly become the main source of Pi for fertilizer production. Despite this abundance, phosphate rock is still a non-renewable resource, which required $10-15$ million years for its production (Cordell et al., 2009). As of 2009, the total mineable phosphate rock reserves were estimated at 15-16 billion tons (containing approximately $30 \% \mathrm{Pi}$ ), according to the US Geological Survey (an organization that collects data worldwide to estimate levels of our natural resources). The gravity of the situation is apparent when it is taken into consideration that 170 million tons of phosphate rock were extracted that same year for fertilizer production. The demand for phosphate rock will only steadily increase, with the mounting concerns to feed a growing global population, and 
the development of plant culture dedicated to biofuel production. These facts clearly strengthen the estimate of remaining Pi rock reserves. According to these data, our Pi rock reserves should be exhausted in only 50-100 years (Gilbert, 2009; Gross, 2010). A $700 \%$ increase in the price of Pi was observed in 2008, foreshadowing the impact that Pi scarcity can have on the economy (Cordell et al., 2009). This underscores an urgent need for an alternative to the use of phosphate rock reserves, which are largely devoted $(82 \%)$ to fertilizer production. Moreover, this production process demands the exploitation of high quality Pi reserves in order to avoid contamination by toxic heavy metals such as cadmium or isotopes of the natural decay series of uranium or thorium (Othman and Al-Masri, 2007; Casacuberta et al., 2011; Da Conceicao et al., 2011). Improving our knowledge of Pi acquisition and use by plants will undoubtedly have a positive effect on reducing the dependency on fertilizer supply for crop production.

Inorganic phosphate concentration in plant tissues has been measured at 5-20 mM (Raghothama, 1999), whereas the level available in soils is typically less than $10 \mu \mathrm{M}$ (Bieleski, 1973). This sharp concentration gradient between the plant and the soil illustrates the crucial role of Pi transporters. The study of the PHT1 family of phosphate transporters is particularly appropriate, due to their presence in the plant plasma membrane (at the interface between the cell and the external medium). Several reviews have focused on this family of transporters (Raghothama, 1999; Smith et al., 2000; Rausch and Bucher, 2002; Smith and Barker, 2002; Bucher, 2007), since the identification of phosphate transporters in Arabidopsis thaliana in 1996 (Muchhal et al., 1996). More recent advances have revealed novel processes that control this family of transporters. The present article will synthesize this literature with special attention to PHT1 regulation and the plant model $A$. thaliana.

\section{IDENTIFICATION OF PHT1 PHOSPHATE TRANSPORTERS}

Beginning in the early 1990s, several high affinity phosphate transporters were cloned in various fungi. The first one, PHO84, was identified in the yeast Saccharomyces cerevisiae (Bun-Ya et al., 1991). Several years later, transporter homologs were found in Neurospora crassa (Versaw, 1995; Versaw and Metzenberg, 1995) and in the mycorrhizal fungus Glomus versiforme (Harrison and Van Buuren, 1995). Their discovery enabled the identification of phosphate transporters in plants. Two separate approaches were used for their identification in Arabidopsis, either by the heterologous complementation of the yeast pho84 mutant by plant cDNA (Muchhal et al., 1996) or by the identification of Arabidopsis ESTs closely related to these proteins (Mitsukawa et al., 1997; Smith et al., 1997). Later, their function as phosphate transporters was confirmed in planta by the analysis of Arabidopsis mutants such as pht1;1 and pht1;4 and the corresponding double mutant (Misson et al., 2004; Shin et al., 2004). The nearly simultaneous identification of these genes by several teams introduced some initial confusion to the literature, as different nomenclatures were proposed (PT or PHT) by these authors. Adding to this confusion, as the genes turned out to belong to a wide multigenic family, several authors published descriptions of different homologs under the same name (Muchhal et al., 1996; Smith et al., 1997; Okumura et al., 1998). Not until the complete sequencing of the $A$. thaliana genome in 2000 was it revealed that the PHT1 family is comprised of nine members (PHT1;1 through PHT1;9; Figure 1). Their names have now been unified according to the rule of the Commission on Plant Gene Nomenclature (Rausch and Bucher, 2002).

Homologs of PHT1 transporters have been characterized in a wide range of species, since their initial identification in Arabidopsis. This non-exclusive list includes: potato (Leggewie et al., 1997), Lupinus albus (Liu et al., 2001), tomato (Daram et al., 1998; Liu et al., 1998a), Catharanthus roseus (Kai et al., 1997), Medicago truncatula (Liu et al., 1998b; Xiao et al., 2006), barley (Smith et al., 1999), tobacco (Baek et al., 2001), lotus (Nakamori et al., 2002), rice (Paszkowski et al., 2002; Ming et al., 2005), maize (Nagy et al., 2006), wheat (Tittarelli et al., 2007), Populus trichocarpa (LothPereda et al., 2011) as well as more distant organisms such as Chlamydomonas (Chang et al., 2005).

\section{PHT1 STRUCTURE}

Sequence analysis of different PHT1 transporters highlights an amino acid sequence conserved from fungi to plants. Hydrophobicity analysis predicts that these transporters share a common topology with 12 membrane-spanning domains, which are separated into two groups of six domains by a charged hydrophilic loop (Raghothama, 1999). Both C- and N-termini are expected to be oriented inside the cell, with the protein inserted in the plasma membrane (Raghothama, 1999). The PHT1 family members encode closely related proteins, as indicated by a greater than $76 \%$ identity in their protein sequences between various plant species (A. thaliana, tomato, M. truncatula, potato, and C. roseus; Raghothama, 1999; cf. Figure 1 for examples). Strong homologies for this protein family are also observed between plants and yeast: Arabidopsis $\mathrm{PHT} 1$ and yeast $\mathrm{PHO} 84$ proteins share $34 \%$ identity and around $50 \%$ similarity.

In Arabidopsis, these transporters range in size from 520 to 550 amino acids, with an estimated molecular weight around $58 \mathrm{kDa}$. As previously reported in Medicago (Chiou et al., 2001) or in Arabidopsis (Figure 2) this weight is lower than expected. Moreover, these western blots exhibit also higher weight molecular bands that are compatible with the presence of multimeric proteins (Figure 2; Chiou et al., 2001). This hypothesis will require further experiments for validation, such as those performed for NRT2.1 (Wirth et al., 2007). In these experiments multimers were also identified on SDS PAGE gel before validation by crosslinking. Nevertheless, this view is also supported by the semi-dominant character of the pht 1;1-3 mutation in Arabidopsis (Catarecha et al., 2007), a trait generally associated with multimeric transporters (Ludewig et al., 2003; Loque et al., 2007) in which incorporating the inactive subunits into the multimeric pore affects its global structure.

\section{PHT1 ARE Pi:H+ CO-TRANSPORTERS}

The study of $\mathrm{Pi}$ uptake kinetics in planta using radioactive $\mathrm{Pi}$ isotopes $\left(\mathrm{P}^{33}\right.$ or $\left.\mathrm{P}^{32}\right)$ identified two distinct phases, which were interpreted as the co-existence of a high and a low affinity system (Cogliati and Clarkson, 1983; Drew and Saker, 1984; Drew et al., 1984). Pi uptake kinetics have been measured for several species (Lemna gibba, Brassica nigra, C. roseus, tobacco, Arabidopsis), with 


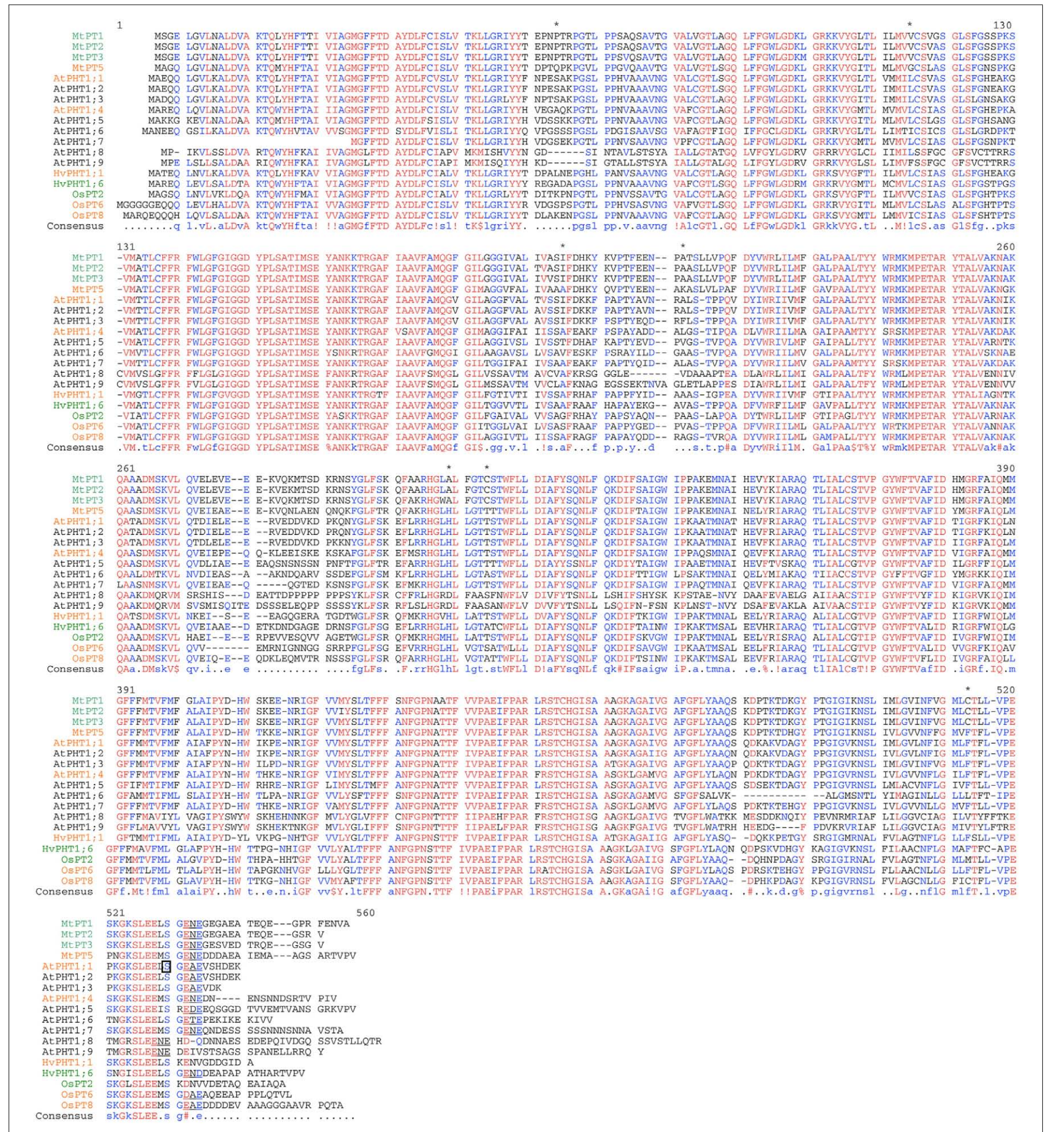

FIGURE 1 | Sequence alignment of several PHT1 transporters from Medicago truncatula (Mt), Arabidopsis thaliana (At), Hordeum vulgare (Hv), and Oryza sativa (Os). High or low affinity characterized PHT1 are indicated by orange or green colors respectively. Stars indicate the 7 amino acids with non-conservative changes between the three low affinity (MtPT1, Mt PT2, MtPT3) and the high affinity transporters (MtPT5) identified by Liu et al. (2008). The serine identified in AtPHT1.1 (Bayle et al., 2011) that regulates exit from the $E R$ is boxed and the putative ER exit site is underlined.
$K_{\mathrm{m}}$ values for the high affinity system in the range of 2.5$12.3 \mu \mathrm{M}$, whereas $K_{\mathrm{m}}$ values for the low affinity system were usually observed between 50 and $100 \mu \mathrm{M}$ (Ullrich-Eberius et al.,
1984; Lefebvre et al., 1990; Furihata et al., 1992; Shimogawara and Usuda, 1995; Dunlop et al., 1997). In rare cases, only high affinity phosphate transporters could be detected (Drew and Saker, 


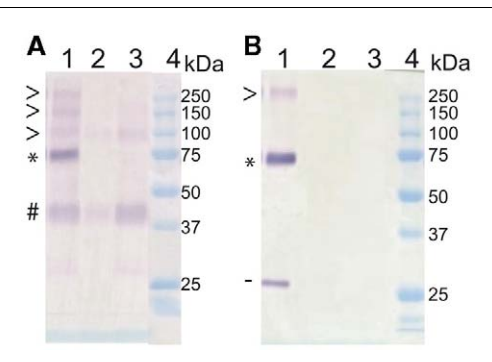

FIGURE 2 |Western blot analysis of PHT1;1, PHT1;2, and PHT1;3 on root membrane protein extracts reveal the presence of potential multimers. Plants were grown in vitro on medium supplemented with high $(500 \mu \mathrm{M})$ or low $(10 \mu \mathrm{M}) \mathrm{Pi}$ content $(+\mathrm{P}$ or $-\mathrm{P}$ respectively). Five micrograms of membrane protein were loaded per lane, on $10 \%$ acrylamide SDS PAGE gels before protein transfer onto nitrocellulose membranes. (A) The primary antibody was designed against two peptides common to $\mathrm{PHT} 1 ; 1, \mathrm{PHT} 1 ; 2$, and PHT1;3. In parallel, an anti GFP antibody (Roche) was used for control western blots at the same dilution (B). Lanes were loaded as follows: (1) Transgenic line expressing 35S:PHT1;1:GFP construct; and wild type control on $+P(2)$ or $-P(3)$ and Bio-Rad Precision Plus Protein Standards (4). GFP tagged (*) and untagged (\#) PHT1 monomeric form, putative multimers (>) and cleaved GFP (-).

1984), and it remains to be determined if this is linked to the plant samples or the experimental design.

Inorganic phosphate uptake is an energy-mediated process that promotes the alkalinization of the medium, which points toward a $\mathrm{Pi} / \mathrm{H}^{+}$co-transport (Ullrich and Novacky, 1990). The measurements of phosphate absorption and proton flux revealed a stoichiometry of two to four protons for each phosphate ion transported across the plasma membrane (Ullrich-Eberius et al., 1981, 1984; Sakano, 1990).

It should be noted that phosphate transporters (in particular PHT1 proteins) can also transport Pi analogs such as phosphite (Ticconi et al., 2001; Varadarajan et al., 2002) and arsenate (Lee et al., 2003; Catarecha et al., 2007; Wu et al., 2011). This last compound is highly toxic and can be found in the soil or water of certain areas. Interestingly, both arsenate and phosphite, like Pi, down-regulate PHT1 transcription (Ticconi et al., 2001; Varadarajan et al., 2002; Catarecha et al., 2007).

\section{A RANGE OF AFFINITIES}

Several approaches have been used to investigate the Pi transport properties of the various PHT1 family members. One approach relies on the complementation by plant phosphate transporters of the yeast pho84 mutant or pho84/pho89 double mutant (PHO84 and $\mathrm{PHO} 89$ are the two major high affinity Pi transporters present in yeast). The $K_{\mathrm{m}}$ values measured for several PHT1 family members were: 280 and $130 \mu \mathrm{M}$, for two of the potato PHT1 transporters (Muchhal et al., 1996; Leggewie et al., 1997; Liu et al., 1998b); $97 \mu \mathrm{M}$ for the rice OsPT6 (Ai et al., 2008) or $23 \mu \mathrm{M}$ for OsPT8 (Jia et al., 2011); and $192 \mu \mathrm{M}$ for Medicago MtPT1 (Liu et al., 1998b).

Although a range of affinities can be determined from yeast complementation assays, in most cases these measurements greatly exceed the expected $K_{\mathrm{m}}$ calculated from in planta radioactive Pi uptake experiments (from 2.5 to $100 \mu \mathrm{M}$ as mentioned in a previous section). This suggests that yeast complementation can only partially reflect the behavior of PHT1 proteins in plants, and it is important to keep this information in mind when predicting the affinities of PHT1 proteins in the plant.

Because of the discrepancies between the in planta affinities and the values obtained in yeast, alternative methods may be needed for precise Pi uptake measurements. One such technique is the heterologous transformation of Xenopus oocytes with PHT1 transporters, although measured affinities based on this method can also largely differ from the expected values in planta. For instance, the rice Pi transporter OsPT2 exhibits low affinity characteristics in the $\mathrm{mM}$ scale, when expressed in oocytes (Ai et al., 2008). By contrast, using the same method reveals a $K_{\mathrm{m}}$ value of $19 \mu \mathrm{M}$ for the barley high affinity Pi transporter HvPHT1 (Preuss et al., 2011). One revealing potential study could be to compare values obtained for both systems (yeast vs. oocytes) for several transporters.

To avoid using a heterologous system, the kinetic parameters can be investigated by gene over-expression in plant cell culture. This technique was used to estimate $K_{\mathrm{m}}$ values for AtPHT1;1 (3.1 $\mu \mathrm{M}$, Mitsukawa et al., 1997), and for barley HvPHT1;1 $(9.06 \mu \mathrm{M})$ and HvPHT1;6 (385 $\mu \mathrm{M}$, Rae et al., 2003). These data are much closer to the affinities expected for Pi uptake measurements in planta, although the high Km determined for HvPHT1;6 reinforces the idea that PHT1 members could encode both high and low affinity transporters.

One study has attempted to identify which amino acid alterations are responsible for the variation observed in transporter affinity, in M. truncatula. The results indicate that slight variations in the protein sequence of the PHT1 proteins could influence their affinity for Pi transport (Liu et al., 2008): when several $M$. truncatula PHT1 transporters with an $84 \%$ amino acid identity were expressed in yeast, their $K_{\mathrm{m}}$ ranged broadly from 13 to $858 \mu \mathrm{M}$. Analysis of the transporter sequences revealed that only seven amino acids showed non-conservative changes between the three low affinity (MtPT1, Mt PT2, MtPT3) and the high affinity transporters (MtPT5). These amino acid positions are located all along the protein sequence (Figure 1). The predicted structural model hypothesizes that they are clustered in two regions of the protein: one on the extracellular surface, and one within the membrane (Liu et al., 2008). The authors posit that these particular extracellular membrane areas could be directly responsible in controlling the PHT1 affinities. Nevertheless, sequence comparisons with other PHT1 transporters that exhibit distinct affinities for Pi could not reveal a correlation with these results (Figure 1). This suggests either independent evolution in separate species, or that the amino acids identified from the M. truncatula data cannot account for affinity changes in other species.

\section{SPATIAL DISTRIBUTION}

Most members of the PHT1 family exhibit strong expression in roots, and this property is shared between monocotyledonous and dicotyledonous species (Muchhal et al., 1996; Leggewie et al., 1997; Smith et al., 1997; Liu et al., 1998a,b; Schunmann et al., 2004a; Koyama et al., 2005; Nagy et al., 2006; Xiao et al., 2006; Tittarelli et al., 2007; Jia et al., 2011; Loth-Pereda et al., 2011). However, PHT1 proteins are also detected in aerial organs such as leaves or flowers (Figure 3). 
More precisely, in situ hybridization performed in tomato revealed the presence of LePT1 transcript in the root cap and in the external layers of the root (Daram et al., 1998; Liu et al., 1998a). Similar experiments in M. truncatula and A. thaliana localized MtPT1 and AtPHT1;4 in the root epidermis and root hairs (Chiou et al., 2001; Misson et al., 2004). Immunoblot analyses of tomato LePT1 (Muchhal and Raghothama, 1999) and potato StPT2 (Gordon-Weeks et al., 2003), or use of translational GFP fusions with either AtPHT1;1, AtPHT1;2, or AtPHT1;4 (Gonzalez et al., 2005; Bayle et al., 2011) have all provided similar results, localizing these transporters mainly in epidermis and root hairs. Additionally, translational fusion experiments between PHT1 and

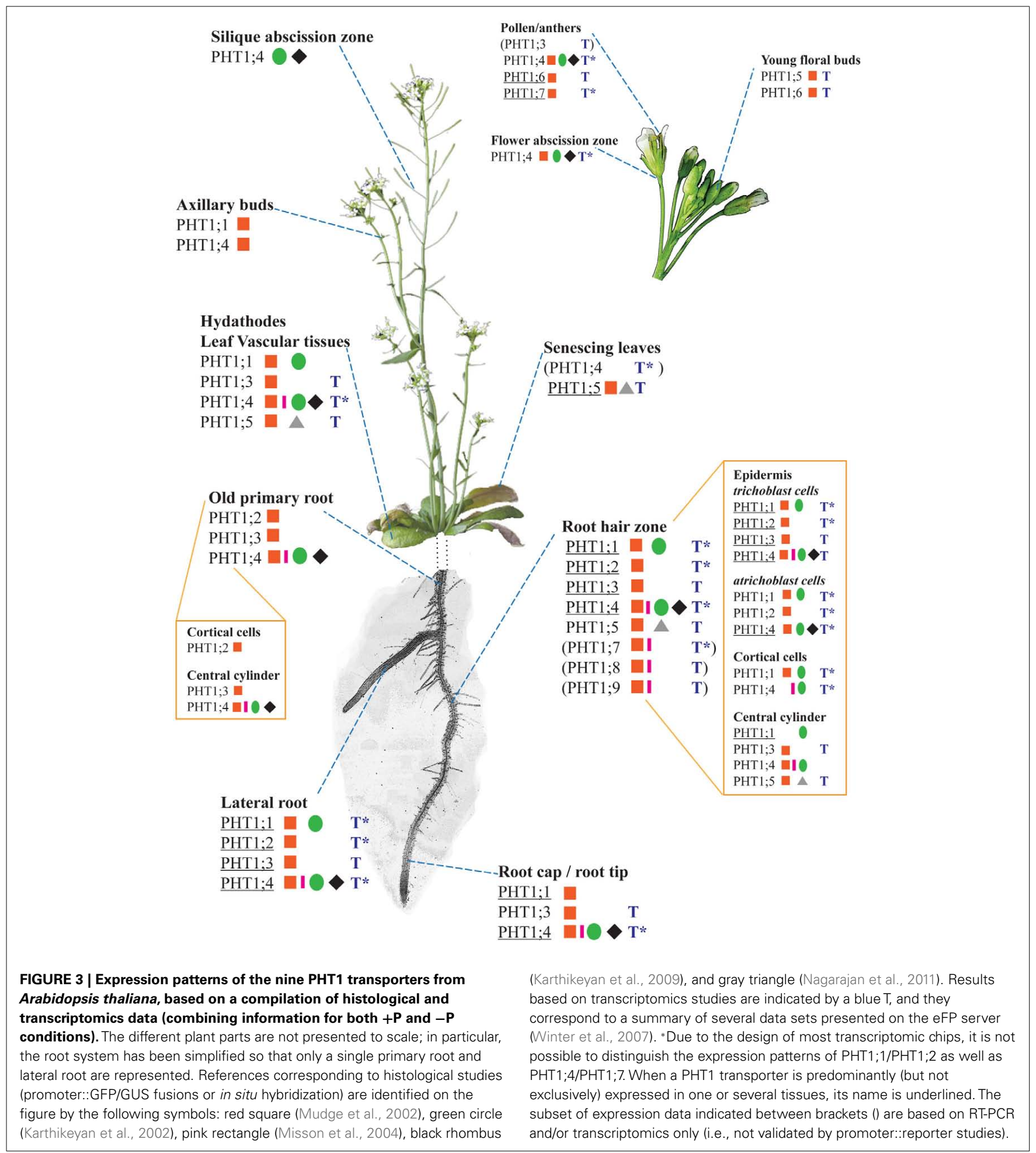


GFP reporter genes confirmed that these phosphate transporters are targeted to the plasma membrane in various species (Gonzalez et al., 2005; Bayle et al., 2011; Jia et al., 2011). Transcriptional fusions between PHT1 promoters and the GUS or GFP reporter genes have also facilitated the study of the expression patterns of PHT1 members from different species, along with the identification of promoter elements involved in the control of these expression patterns (Karthikeyan et al., 2002; Mudge et al., 2002; Schunmann et al., 2004a,b; Misson et al., 2005; Jia et al., 2011). In the specific case of the plant model $A$. thaliana, the full genome sequence permitted extensive analyses of all Arabidopsis PHT1 family members, using either RT-PCR (Mudge et al., 2002; Misson et al., 2005) or promoter fusions with GUS or GFP reporter genes (Karthikeyan et al., 2002; Mudge et al., 2002). A landmark contribution to this field was provided by Mudge et al. (2002), who performed a systematic study of the nine PHT1 transporters. Subsequently, the expression patterns were confirmed or analyzed more precisely by several other laboratories (Karthikeyan et al., 2002, 2009; Misson et al., 2004; Nagarajan et al., 2011). In addition, the publication of multiple transcriptomics studies allows us to take into account data sets that were not initially developed for the study of phosphate transport. Powerful tools such as the eFP browser provide an efficient way of analyzing this vast amount of data (Winter et al., 2007). Figure 3 summarizes the expression patterns for the nine PHT1 members of $A$. thaliana, and compares their published expression patterns to values contained within transcriptomics data sets.

It appears that the vast majority of the transporters (eight of the nine Arabidopsis PHT1 members) are expressed at least in roots, in line with their major role in Pi uptake from the soil. Within the roots, the expression of phosphate transporters is mostly concentrated in root epidermis and central cylinder, particularly in the root hair zone (Karthikeyan et al., 2002; Mudge et al., 2002; Misson et al., 2004; Koyama et al., 2005; Xiao et al., 2006; Hirsch et al., 2011).

Most PHT1 transporters are not present in a single cell type, but are found in diverse tissues from various organs, often in overlapping patterns with other PHT1 members, suggesting a greater complexity in their roles (Karthikeyan et al., 2002; Mudge et al., 2002; Figure 3). However, each PHT1 member taken individually is defined by a preferential expression in a given tissue, which may indicate the location of its predominant role. It should be noted that this location is often strongly influenced by environmental or developmental factors. For instance, strong AtPHT1;6 expression in pollen could reveal a role for PHT1 transporters during flower development (Karthikeyan et al., 2002; Mudge et al., 2002). Functional confirmation of these expression patterns can be performed by reverse genetic analyses: the role of PHT1 protein in soil Pi uptake was demonstrated with Arabidopsis pht1;4 and pht1;1 single and double mutants, which are dramatically attenuated in their phosphate uptake capacities (Misson et al., 2004; Shin et al., 2004). A similar strategy was recently applied to understand the importance of the strong expression of PHT1;5 in senescing leaves (Nagarajan et al., 2011; Figure 2): analysis of the pht1;5 mutant confirmed a role in senescing leaves, and revealed its role in sourceto-sink Pi mobilization. Altogether, this literature suggests a major role for PHT1 transporters in Pi uptake from soil, and additional roles in Pi re-mobilization from other organs.

One category of PHT1 transporters which cannot be studied in Arabidopsis are the PHT1 transporters that are induced by mycorrhizal symbiosis (endo and ectomycorhizal associations). Arabidopsis is among the minority of plants which is incapable of establishing any symbiosis with mycorrhizal fungi. This symbiosis is however widespread among the plant kingdom (80\% of vascular plants), and its impact on the capacity of plants to acquire Pi from the soil has been well established (Smith and Read, 1997). This adaptation of plants has probably evolved to benefit from the ability of the fungus to explore a greater part of the soil (exploring up to 100 -fold more soil volume) and to have access to mineralized organic phosphorus (Bucher, 2007).

The induction of specific plant PHT1 transporters in response to mycorrhization is a widely reported feature of these symbioses (Javot et al., 2007b; Hata et al., 2010; Loth-Pereda et al., 2011). In the case of the endomycorrhizal symbiosis, the fungus penetrates into the root system and develops hyphal structures (referred to as arbuscules) in the cortex. These arbuscules are composed of a trunk and arbuscular branches, which are enveloped by the plasma membrane of the cortical cell. The expression of a subset of PHT1 members is induced in cells containing arbuscules, which are believed to be the site of nutrient exchange between the plant and the fungus (Smith and Read, 1997; Javot et al., 2007a; Loth-Pereda et al., 2011). The symbiosis-specific PHT1 phosphate transporter MtPT4 from the plant M. truncatula is only detected in cells containing arbuscules, and it has exclusively been located in the plasma membrane that surrounds arbuscular branches (Pumplin and Harrison, 2009). The fine regulation of arbuscule development and associated stimulation of PHT1 expression was recently illustrated by the study of the dynamics of the rice transporter OsPT11 fused to GFP (Kobae and Hata, 2010).

Promising techniques using uptake of radioactive Pi isotopes in planta can be applied to study specific PHT1 transporters. It is now possible to visualize and analyze the precise dynamics of Pi distribution in planta. This technique, using X-ray films or imaging plates, has revealed that the main location for phosphate uptake in Arabidopsis is found close to the root tips, and that PHT1 proteins are involved in this process (Misson et al., 2004). A recent improvement in visualizing Pi flux dynamics is the use of a CsI scintillator to convert $\beta$-rays into visible light (Kanno et al., 2007). As illustrated in Figure 4, it is now possible to compare precisely and in a non-destructive way the entry of $\mathrm{Pi}$ into various genotypes of plants at the same time (in particular for mutations affecting PHT1 transporters).

\section{TRANSCRIPTIONAL REGULATION OF PHT1 TRANSPORTERS}

The tissue specificity of PHT1 described above appears to be mostly controlled at the transcriptional level. It is likely that the spatial distribution of PHT1 proteins requires regulatory elements located in the promoters, which remain poorly characterized (Schunmann et al., 2004a,b; Karthikeyan et al., 2009). Nevertheless, they are probably well conserved between monocots and dicots, since fusion of the AtPHT1;1 promoter with the GUS reporter gene has given fairly similar expression patterns 

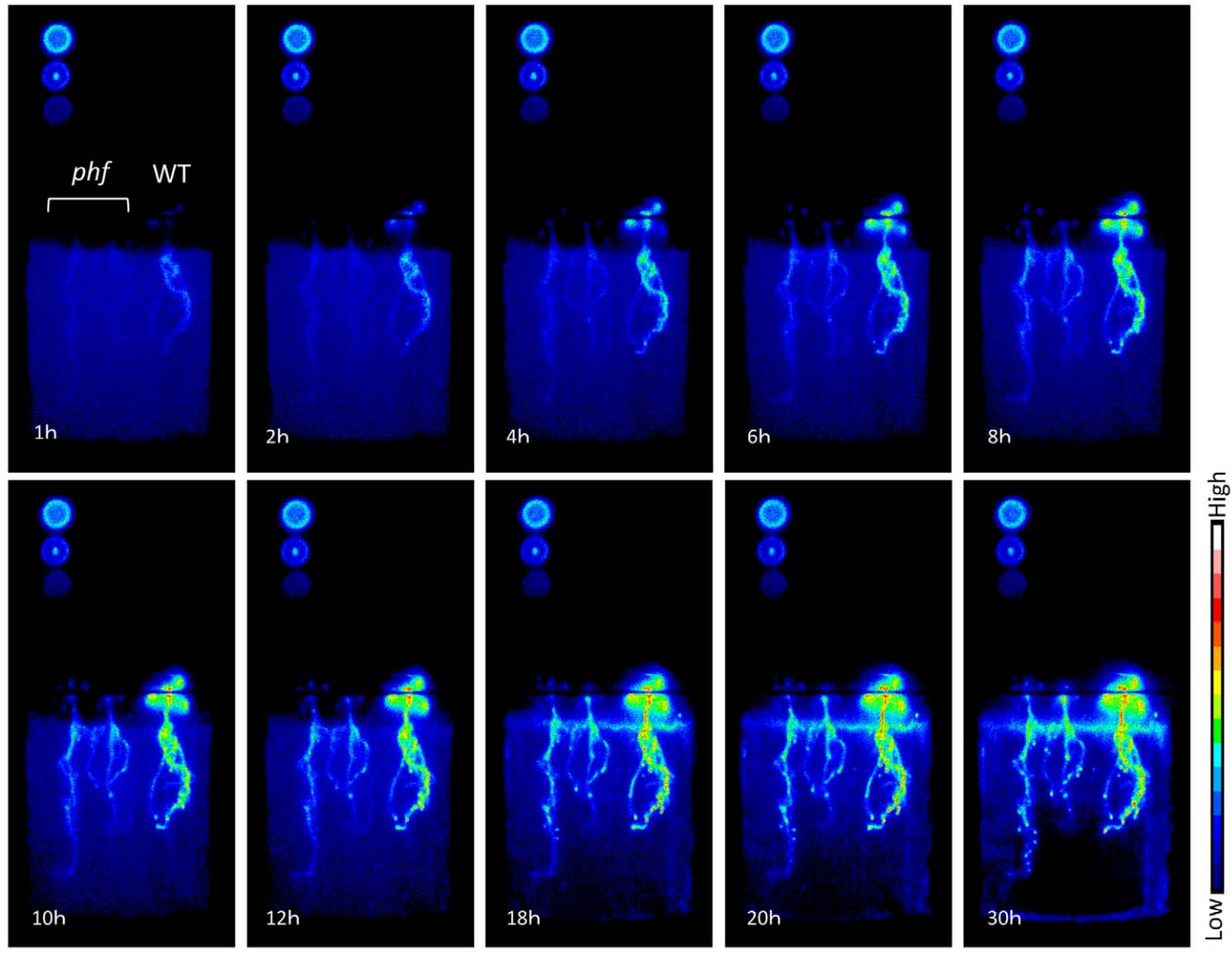

FIGURE 4 |Time course for phosphate absorption based on ${ }^{32} \mathrm{P}$ detection in Arabidopsis. Plants were supplied with $10 \mu \mathrm{M} \mathrm{Pi}$ with ${ }^{32} \mathrm{P}\left(\mathrm{H}_{3} \mathrm{PO}_{4}, 12.5 \mathrm{kBq} / \mathrm{ml}\right)$. Images of radioactivity were obtained every $3 \mathrm{~min}$; 10 images are presented here. For each panel, two phf mutants (left) and one wild type (Col-0; right) plantlet are shown. Circles on the left are ${ }^{32} \mathrm{P}$ standards:descending from the upper left corner, they represent 2.5, 1, and $0.5 \mathrm{k} \mathrm{Bq} / \mu \mathrm{l}$. The plants shown are 11 days old, grown in vitro using 1/10 MS medium containing $500 \mu \mathrm{M} \mathrm{Pi}$ and subsequently transferred to $10 \mu \mathrm{M}$ Pi for 3 days before analysis. in both rice and Arabidopsis transformants (Koyama et al., 2005).

The expression of specific plant PHT1 transporters that are induced in roots in response to mycorrhizal symbiosis is also under transcriptional control in species as diverse as: rice (Paszkowski et al., 2002), Medicago (Harrison et al., 2002; Javot et al., 2007a), potato (Nagy et al., 2005), maize (Nagy et al., 2006), various cereals (Glassop et al., 2005), tomato (Nagy et al., 2005; Balestrini et al., 2007; Xu et al., 2007), and trees such as poplar (Loth-Pereda et al., 2011).

The internal Pi concentration of cells is a major factor in the control of PHT1 expression. This role has been clearly illustrated by various transcriptomics experiments (Hammond et al., 2003; Wu et al., 2003; Misson et al., 2005; Morcuende et al., 2007; Winter et al., 2007; Calderon-Vazquez et al., 2008; Bustos et al., 2010; Thibaud et al., 2010), or with the assistance of reporter genes (Karthikeyan et al., 2002; Mudge et al., 2002; Misson et al., 2004.). Interestingly, plants can adjust PHT1 transcription when challenged with a broad spectrum of Pi concentrations (from 0 to $1250 \mu \mathrm{M})$ that are outside of the expected range in soils, typically observed below $10 \mu \mathrm{M}$ (Muchhal and Raghothama, 1999;
Karthikeyan et al., 2002; Misson et al., 2004). Low basal levels of gene expression are usually observed when the Pi concentration of the medium exceeds $250 \mu \mathrm{M}$ (Muchhal and Raghothama, 1999; Karthikeyan et al., 2002; Misson et al., 2004).

Variation of Pi concentration in the medium promotes a rapid modulation of PHT1 transcripts. In Arabidopsis, the detection of Pi deficiency can occur within 12-24h after removal of Pi from the medium (Muchhal and Raghothama, 1999; Misson et al., 2004, 2005). Not surprisingly, re-supply of Pi triggered a faster response (Karthikeyan et al., 2002), presumably since Pi accumulation occurs more rapidly than its depletion from the vacuole (Stefanovic et al., 2011). This phenomenon can be greatly affected by the protocol for cultivating plants (hydroponics vs. solid medium), as gelling agents are often contaminated with traces of $\mathrm{Pi}$, which can impact the responses of the plant (Jain et al., 2009). The analysis of promoter sequences from barley, wheat, and Arabidopsis PHT1 transporters prompted the identification of regulatory boxes involved in the response to Pi starvation (Schunmann et al., 2004b; Tittarelli et al., 2007; Karthikeyan et al., 2009; Thibaud et al., 2010). These studies revealed the presence of the P1BS motif, which is the binding site for the R2R3 Myb transcription 
factor PHR1 (PHOSPHATE STARVATION RESPONSE 1, Rubio et al., 2001; Nilsson et al., 2007) in Arabidopsis. This protein is a homolog of Chlamydomonas reinhardtii protein PSR1 (PHOSPHORUS STARVATION RESPONSE 1, Wykoff et al., 1999). PHR1 belongs to a wide multigenic family that includes PHL1 (Bustos et al., 2010). Both PHR1 and PHL1 bind to the P1BS DNA motif (GNATATNC; Rubio et al., 2001), and play a crucial role in the Pi responsiveness of PHT1 transporters as demonstrated with both phrl and phrl/phl1 mutants (Rubio et al., 2001; Bustos et al., 2010). This DNA binding motif appears to be conserved between monocots and dicots (Zhou et al., 2008). In addition, the P1BS motif participates in the systemically regulated $P H T 1$ response to internal Pi concentration, as revealed by the full genome analysis in split root experiments (Thibaud et al., 2010).

Additional regulatory sequences have been proposed from in silico analyses (including HLH, and NIT2 motifs highly present in the promoters of the PHT1 genes), although no mechanism has been characterized yet (Mukatira et al., 2001). The genes PHO1 and $\mathrm{PHO} 2$ have also been identified as critical to the control of Pi homeostasis (Hamburger et al., 2002; Aung et al., 2006; Bari et al., 2006). The corresponding pho1 and pho2 mutants accumulate $\mathrm{Pi}$ in either roots or leaves, respectively (Poirier et al., 1991; Delhaize and Randall, 1995), and affect the transcription of PHT1;8 and PHT1;9 (Bari et al., 2006; Rouached et al., 2011). It is likely that PHO1 (membrane protein of unknown function) and $\mathrm{PHO} 2$ (E2 conjugase protein) act along with additional elements, since neither of these two proteins are transcription factors.

Several transcription factors have been found in addition to PHR1 that regulate PHT1 expression. For example, genetic dissection of the AtPHT1;4 promoter identified putative binding sequences for AtMyb2 and AtMyc2 (two positive regulators responding to water deprivation and abscisic acid stimuli) and also WRKY proteins (Karthikeyan et al., 2009), which are involved in biotic and abiotic stress responses. Reducing WRKY75 expression through RNAi silencing (Devaiah et al., 2007a) or the over-expression of MYB62 (Devaiah et al., 2009) produces plants that exhibit a decreased level of several PHT1 transporters, although there is no evidence for a direct interaction between these transcription factors and PHT1 promoters.

Further regulatory components were identified based on genetic evidence and transcriptomic analysis of Pi starvation. These include the zinc finger transcription factor ZAT6 (Devaiah et al., 2007b), the regulatory protein SPX3 (Duan et al., 2008), the nuclear actin-related protein ARP6, and the histone H2A.Z (Smith et al., 2010). These various proteins are reported to modulate PHT1 genes (see Chiou and Lin, 2011 for a recent review of the Pi regulatory pathway), although a mechanism of action remains to be proposed.

Factors other than Pi concentration also influence PHT1 expression, including active photosynthesis or sugars (Jain et al., 2007; Karthikeyan et al., 2007; Hammond and White, 2008, 2011; Lei et al., 2011). Cytokinins have also been observed to prevent PHT1 induction during Pi deficiency; this action relies on the cytokinin receptors CRE1/AHK3 and AHK4 (FrancoZorrilla et al., 2002, 2005). Many genes responding to Pi deficiency are stimulated by sugars or are enhanced in the crel/ahk4 mutant (regardless of cytokinin applications), suggesting crosstalk between Pi deficiency, sugars, and cytokinin (Franco-Zorrilla et al., 2005).

\section{POST-TRANSCRIPTIONAL REGULATION OF PHT1}

Beyond transcriptional control, PHT1 targeting and accumulation in the plasma membrane are also modulated by multiple steps of post-translational regulations. A mutant allele of the PHF1 locus (PHOSPHATE TRANSPORTER TRAFFIC FACILITATOR1) has been identified, which displays a severe decrease in Pi influx (Gonzalez et al., 2005). In accordance with its status as an endoplasmic reticulum (ER) resident protein, the loss of PHF1 results in the abnormal accumulation of PHT1;1, PHT1;2, and PHT $1 ; 4$ in the ER, suggesting that PHF1 could be involved in intracellular trafficking of several PHT1 family proteins (Gonzalez et al., 2005; Bayle et al., 2011). These observations can explain how the phf1-1 mutant shows a strong reduction $(80 \%)$ of $\mathrm{Pi}$ uptake capacity compared to WT when grown in low Pi (Gonzalez et al., 2005; Figure 4). Recently, similar results were found in rice, where a mutant of OsPHF1 was shown to affect several members of PHT1 family, including the low affinity Pi transporter OsPT2 and the high affinity Pi transporter OsPT8 (Chen et al., 2011). A similar targeting defect was described for axr4, an auxin-resistant mutant that is affected in the expression of an ER accessory protein; this defect promotes the retention of the auxin influx facilitator AUX1 in the ER (Dharmasiri et al., 2006). These results suggest that several membrane proteins may require assistance in transiting through the ER compartment. PHF1 exhibits structural homologies with yeast SEC12 protein, an ER resident component involved in the formation of COPII vesicles (Gonzalez et al., 2005). These vesicles are involved in the export of newly synthesized cargo proteins, including PHT1, from the ER to the Golgi apparatus in eukaryotic cells. Although PHF1 shares structural homologies with SEC12, multiple amino acids that have been conserved between all SEC12 proteins are lost in the plant PHF1 homologs. This suggests a functional specialization that has diverged from that of SEC12 (Gonzalez et al., 2005). Indeed, cell biology experiments in Arabidopsis revealed the absence of colocalization between COPII markers and PHF1, demonstrating the independence of PHF1's role from COPII formation (Bayle et al., 2011).

Phospho-proteomic studies have determined that phosphorylation events occur at the C-end of PHT1 proteins when Pi is abundant in the environment (Nuhse et al., 2004; Hem et al., 2007). A phosphorylation-mimicking mutagenesis of PHT1;1 (at Ser 514, Figure 1) resulted in its accumulation in the ER (Bayle et al., 2011), implicating phosphorylation as an additional way for plant cells to modulate PHT1 exit from the ER. Phosphorylation events on serine residues located at the C-end of the PHT1;1 protein could provide additional negative charges in the vicinity of the putative ER export site (D/E-X-D/E), thereby altering the recognition of this motif and resulting in the accumulation of PHT1;1 in the ER (Figure 1). This mechanism is likely conserved between the different PHT1 transporters, since phosphorylation of other Arabidopsis members of this family (PHT1;4, PHT1;5; PHT1;7, PHT1;9) at the C-end of the protein has been reported (Bayle et al., 2011). This regulation recalls the previously identified phosphorylation 
of the C-terminal serine residue during subcellular trafficking of PIP2;1 toward the plasma membrane (Prak et al., 2008). However, phosphorylation has distinct effects on these proteins. Whereas phosphorylation of PIP2;1 is required for its proper localization, in the case of PHT1;1, phosphorylation was found to prevent the protein from reaching its final destination.

Finally, a new type of post-transcriptional regulation has recently been identified, which specifically degrades plasma membrane PHT1 in the presence of phosphate (Bayle et al., 2011). This mechanism is dependent upon endocytosis and subsequent degradation of the protein in the vacuole. Similar regulatory mechanisms have been identified for many types of plasma membrane proteins in yeast, plants, and animals (Lagerstedt et al., 2002; Persson et al., 2003; Takano et al., 2005). As for the broader family of $\mathrm{Pi}$ transporters, this regulation has already been reported for the yeast PHO84 transporter (Lagerstedt et al., 2002; Persson et al., 2003). An important distinction here is that the regulatory mechanism identified in yeast requires the phosphorylation of an amino acid to observe this degradation phenomenon, whereas this particular amino acid is not conserved in plant PHT1 (Lundh et al., 2009). Thus, despite the high homologies between PHO84 and PHT1

\section{REFERENCES}

Ai, P., Sun, S., Zhao, J., Fan, X., Xin, W., Guo, Q., Yu, L., Shen, Q., Wu, P., Miller, A. J., and Xu, G. (2008). Two rice phosphate transporters, OsPht1;2 and OsPht1;6, have different functions and kinetic properties in uptake and translocation. Plant $J$. 57, 798-809.

Aung, K., Lin, S. I., Wu, C. C., Huang, Y. T., Su, C. L., and Chiou, T. J. (2006). pho2, a phosphate overaccumulator, is caused by a nonsense mutation in a microRNA399 target gene. Plant Physiol. 141, 1000-1011.

Baek, S. H., Chung, I. M., and Yun, S. J. (2001). Molecular cloning and characterization of a tobacco leaf cDNA encoding a phosphate transporter. Mol. Cells 11, 1-6.

Balestrini, R., Gomez-Ariza, J., Lanfranco, L., and Bonfante, P. (2007). Laser microdissection reveals that transcripts for five plant and one fungal phosphate transporter genes are contemporaneously present in arbusculated cells. Mol. Plant Microbe Interact. 20, 1055-1062.

Bari, R., Datt Pant, B., Stitt, M., and Scheible, W. R. (2006). PHO2, microRNA399, and PHR1 define a phosphate-signaling pathway in plants. Plant Physiol. 141, 988-999.

Bayle, V., Arrighi, J. F., Creff, A., Nespoulous, C., Vialaret, J., Rossignol, M., Gonzalez, E., Paz-Ares, J., and Nussaume, L. (2011). Arabidopsis thaliana high-affinity phosphate transporters exhibit multiple levels of posttranslational regulation. Plant Cell 23, 1523-1535.
Bieleski, R. L. (1973). Phosphate pools, phosphate transport, and phosphate availability. Annu. Rev. Plant Physiol. $24,225-252$.

Bucher, M. (2007). Functional biology of plant phosphate uptake at root and mycorrhiza interfaces. New Phytol. 173, 11-26.

Bun-Ya, M., Nishimura, M., Harashima, S., and Oshima, Y. (1991). The PHO84 gene of Saccharomyces cerevisiae encodes an inorganic phosphate transporter. Mol. Cell. Biol.11, 3229-3238.

Bustos, R., Castrillo, G., Linhares, F., Puga, M. I., Rubio, V., Perez-Perez, J., Solano, R., Leyva, A., and Paz-Ares, J. (2010). A central regulatory system largely controls transcriptional activation and repression responses to phosphate starvation in Arabidopsis. PLoS Genet. 6, e1001102. doi:10.1371/journal.pgen.1001102

Calderon-Vazquez, C., Ibarra-Laclette, E., Caballero-Perez, J., and HerreraEstrella, L. (2008). Transcript profiling of Zea mays roots reveals gene responses to phosphate deficiency at the plant- and species-specific levels. J. Exp. Bot. 59, 2479-2497.

Casacuberta, N., Masque, P., and GarciaOrellana, J. (2011). Fluxes of (238)U decay series radionuclides in a dicalcium phosphate industrial plant. $J$. Hazard. Mater. 190, 245-252.

Catarecha, P., Segura, M. D., FrancoZorrilla, J. M., Garcia-Ponce, B., Lanza, M., Solano, R., Paz-Ares, J., and Leyva, A. (2007). A mutant of the Arabidopsis phosphate transporter PHT1;1 displays enhanced

proteins, similar regulatory mechanisms could rely on distinct types of machineries. This probably reflects adaptive steps used by plants to cope with a complex environment and a multicellular organization.

\section{CONCLUSION}

Great strides have been made in the characterization of the PHT1 family of Pi transporters since their identification in 1996. The fact that these transporters belong to broad multigenic family often exhibiting overlapping expression patterns limits the analysis of their role in planta. Another obstacle to the characterization of PHT1 proteins is their hydrophobic nature, which has impeded the study of their biochemistry and structural biology. This issue will eventually be surmounted as improved techniques in genetics, cell and molecular biology become more readily available. In view of the ever-expanding array of tools available to researchers, rapid advances are anticipated in our understanding of the finely regulated, sophisticated mechanisms of the PHT1 family.

\section{ACKNOWLEDGMENTS}

We thank Dr. Brandon Loveall (from the "Improvence" editing company) for English proof reading of the manuscript.

arsenic accumulation. Plant Cell 19, 1123-1133.

Chang, C. W., Moseley, J. L., Wykoff, D., and Grossman, A. R. (2005). The LPB1 gene is important for acclimation of Chlamydomonas reinhardtii to phosphorus and sulfur deprivation. Plant Physiol. 138, 319-329.

Chen, J. Y., Liu, Y., Ni, J., Wang, Y. F. Bai, Y. H., Shi, J., Gan, J., Wu, Z. C., and $\mathrm{Wu}, \mathrm{P}$. (2011). OsPHF1 regulates the plasma membrane localization of low- and high-affinity inorganic phosphate transporters and determines inorganic phosphate uptake and translocation in rice. Plant Physiol. 157, 269-278.

Chiou, T. J., and Lin, S. I. (2011) Signaling network in sensing phosphate availability in plants. Annu. Rev. Plant Biol. 62, 185-206.

Chiou, T. J., Liu, H., and Harrison, M. J. (2001). The spatial expression patterns of a phosphate transporter (MtPT1) from Medicago truncatula indicate a role in phosphate transport at the root/soil interface. Plant J. 25, 281-293.

Cogliati, D. H., and Clarkson, D. T. (1983). Physiological changes in, and phosphate uptake by potato plants during development of and recovery from phosphate deficiency. Physiol. Plant 58, 287-294.

Cordell, D., Drangert, J.-O., and White, S. (2009). The story of phosphorus: global food security and food for thought. Glob. Environ. Change 19, 292-305.

Da Conceicao, F. T., Antunes, M. L., and Durrant, S. F. (2011).
Radionuclide concentrations in raw and purified phosphoric acids from Brazil and their processing wastes: implications for radiation exposures. Environ. Geochem. Health. doi: 10.1007/s10653-011-9394-2

Daram, P., Brunner, S., Persson, B. L., Amrhein, N., and Bucher, M. (1998). Functional analysis and cell-specific expression of a phosphate transporter from tomato. Planta 206, 225-233.

Delhaize, E., and Randall, P. J. (1995). Characterization of a phosphateaccumulator mutant of Arabidopsis thaliana. Plant Physiol. 107, 207-213.

Devaiah, B. N., Karthikeyan, A. S. and Raghothama, K. G. (2007a). WRKY75 transcription factor is a modulator of phosphate acquisition and root development in Arabidopsis. Plant Physiol. 143, 1789-1801.

Devaiah, B. N., Nagarajan, V. K., and Raghothama, K. G. (2007b). Phosphate homeostasis and root development in Arabidopsis are synchronized by the zinc finger transcription factor ZAT6. Plant Physiol. 145, 147-159.

Devaiah, B. N., Madhuvanthi, R., Karthikeyan, A. S., and Raghothama, K. G. (2009). Phosphate starvation responses and gibberellic acid biosynthesis are regulated by the MYB62 transcription factor in Arabidopsis. Mol. Plant 2, 43-58.

Dharmasiri, S., Swarup, R., Mockaitis, K., Dharmasiri, N., Singh, S. K., Kowalchyk, M., Marchant, A., Mills, S., Sandberg, G., Bennett, M. J., 
and Estelle, M. (2006). AXR4 is required for localization of the auxin influx facilitator AUX1. Science 312, 1218-1220.

Drew, M. C., and Saker, L. R. (1984). Uptake and long-distance transport of phosphate, potassium and chloride in relation to internal ion concentrations in barley - evidence of non-allosteric regulation. Planta 160, 500-507.

Drew, M. C., Saker, L. R., Barber, S. A., and Jenkins, W. (1984). Changes in the kinetics of phosphate and potassium absorption in nutrient-deficient barley roots measured by a solution-depletion technique. Planta 160, 490-499.

Duan, K., Yi, K., Dang, L., Huang, H., Wu, W., and Wu, P. (2008). Characterization of a sub-family of Arabidopsis genes with the SPX domain reveals their diverse functions in plant tolerance to phosphorus starvation. Plant J. 54 965-975.

Dunlop, J., Phung, H. T., Meeking, R., and White, D. W. R. (1997). The kinetics associated with phosphate absorption by Arabidopsis and its regulation by phosphorus status. Aust. J. Plant Physiol. 24, 623-629.

Franco-Zorrilla, J. M., Martin, A. C., Leyva, A., and Paz-Ares, J. (2005). Interaction between phosphatestarvation, sugar, and cytokinin signaling in Arabidopsis and the roles of cytokinin receptors CRE1/AHK4 and AHK3. Plant Physiol. 138, 847-857.

Franco-Zorrilla, J. M., Martin, A. C., Solano, R., Rubio, V., Leyva, A., and Paz-Ares, J. (2002). Mutations at CRE1 impair cytokinin-induced repression of phosphate starvation responses in Arabidopsis. Plant J. 32, 353-360.

Furihata, T., Suzuki, M., and Sakurai, H. (1992). Kinetic characterization of two phosphate uptake systems with different affinities in suspensioncultured Catharanthus roseus protoplants. Plant Cell Physiol. 33, 1151-1157.

Gilbert, N. (2009). Environment: the disappearing nutrient. Nature 461, 716-718.

Glassop, D., Smith, S. E., and Smith, F. W. (2005). Cereal phosphate transporters associated with the mycorrhizal pathway of phosphate uptake into roots. Planta 222, 688-698.

Gonzalez, E., Solano, R., Rubio, V., Leyva, A., and Paz-Ares, J. (2005). Phosphate transporter traffic facilitatorl is a plant-specific SEC12related protein that enables the endoplasmic reticulum exit of a high-affinity phosphate transporter in Arabidopsis. Plant Cell 17, 3500-3512.

Gordon-Weeks, R., Tong, Y., Davies, T. G., and Leggewie, G. (2003). Restricted spatial expression of a high-affinity phosphate transporter in potato roots. J. Cell. Sci. 116, 3135-3144.

Gross, M. (2010). Fears over phosphorus supplies. Curr. Biol. 20, R386R387.

Hamburger, D., Rezzonico, E., Macdonald-Comber Petetot, J., Somerville, C., and Poirier, Y. (2002). Identification and characterization of the Arabidopsis $\mathrm{PHO} 1$ gene involved in phosphate loading to the xylem. Plant Cell 14,889-902.

Hammond, J. P., Bennett, M. J., Bowen, H. C., Broadley, M. R., Eastwood, D. C., May, S. T., Rahn, C., Swarup, R., Woolaway, K. E., and White, P. J. (2003). Changes in gene expression in Arabidopsis shoots during phosphate starvation and the potential for developing smart plants. Plant Physiol. 132, 578-596.

Hammond, J. P., and White, P. J. (2008). Sucrose transport in the phloem: integrating root responses to phosphorus starvation. J. Exp. Bot. 59, 93-109.

Hammond, J. P., and White, P. J. (2011). Sugar signalling in root responses to low P availability. Plant Physiol. 156, 1033-1040.

Harrison, M. J., Dewbre, G. R., and Liu, J. (2002). A phosphate transporter from Medicago truncatula involved in the acquisition of phosphate released by arbuscular mycorrhizal fungi. Plant Cell 14, 2413-2429.

Harrison, M. J., and Van Buuren, M. L. (1995). A phosphate transporter from the mycorrhizal fungus Glomus versiforme. Nature 378, 626-629.

Hata, S., Kobae, Y., and Banba, M. (2010). Interactions between plants and arbuscular mycorrhizal fungi. Int. Rev. Cell Mol. Biol. 281, 1-48.

Hem, S., Rofidal, V., Sommerer, N., and Rossignol, M. (2007). Novel subsets of the Arabidopsis plasmalemma phosphoproteome identify phosphorylation sites in secondary active transporters. Biochem. Biophys. Res. Commun. 363, 375-380.

Hirsch, J., Marin, E., Floriani, M., Chiarenza, S., Richaud, P., Nussaume, L., and Thibaud, M. C. (2006). Phosphate deficiency promotes modification of iron distribution in Arabidopsis plants. Biochimie 88, 1767-1771.

Hirsch, J., Misson, J., Crisp, P. A., David, P., Bayle, V., Estavillo, G. M., Javot, H., Chiarenza, S., Mallory, A. C., Maizel, A., Declerck, M., Pogson, B. J., Vaucheret, H.,
Crespi, M., Desnos, T., Thibaud, M. C., Nussaume, L., and Marin, E. (2011). A novel fryl allele reveals the existence of a mutant phenotype unrelated to $5^{\prime} \rightarrow 3^{\prime}$ exoribonuclease (XRN) activities in Arabidopsis thaliana roots. PLoS ONE 6, e16724. doi:10.1371/journal.pone.0016724

Jain, A., Poling, M. D., Karthikeyan, A. S., Blakeslee, J. J., Peer, W. A., Titapiwatanakun, B., Murphy, A. S., and Raghothama, K. G. (2007). Differential effects of sucrose and auxin on localized phosphate deficiencyinduced modulation of different traits of root system architecture in Arabidopsis. Plant Physiol. 144, 232-247.

Jain, A., Poling, M. D., Smith, A. P., Nagarajan, V. K., Lahner, B. Meagher, R. B., and Raghothama, K. G. (2009). Variations in the composition of gelling agents affect morphophysiological and molecular responses to deficiencies of phosphate and other nutrients. Plant Physiol. 150, 1033-1049.

Javot, H., Penmetsa, R. V., Terzaghi, N., Cook, D. R., and Harrison, M. J. (2007a). A Medicago truncatula phosphate transporter indispensable for the arbuscular mycorrhizal symbiosis. Proc. Natl. Acad. Sci. U.S.A. 104, 1720-1725.

Javot, H., Pumplin, N., and Harrison, M. J. (2007b). Phosphate in the arbuscular mycorrhizal symbiosis: transport properties and regulatory roles. Plant Cell Environ. 30, 310-322.

Jia, H., Ren, H., Gu, M., Zhao, J., Sun, S., Zhang, X., Chen, J., Wu, P., and $\mathrm{Xu}, \mathrm{G}$. (2011). The phosphate transporter gene OsPht $1 ; 8$ is involved in phosphate homeostasis in rice. Plant Physiol. 156, 1164-1175.

Jouhet, J., Marechal, E., and Block, M. A. (2007). Glycerolipid transfer for the building of membranes in plant cells. Prog. Lipid Res. 46, 37-55.

Kai, M., Masuda, Y., Kikuchi, Y., Osaki, M., and Tadano, T. (1997). Isolation and characterization of a cDNA from Catharanthus roseus which is highly homologous with phosphate transporter. Soil Sci. Plant Nutr. 43 227-235.

Kanno, S., Rai, H., Ohya, T., Hayashi, Y., Tanoi, K., and Nakanishi, T. M. (2007). Real-time imaging of radioisotope labeled compounds in a living plant. J. Radioanal. Nucl. Chem. 272, 565-570.

Karthikeyan, A. S., Ballachanda, D. N., and Raghothama, K. G. (2009). Promoter deletion analysis elucidates the role of cis elements and 5'UTR intron in spatiotemporal regulation of AtPht 1;4 expression in Arabidopsis. Physiol. Plant 136, 10-18.
Karthikeyan, A. S., Varadarajan, D. K., Jain, A., Held, M. A., Carpita, N. C., and Raghothama, K. G. (2007). Phosphate starvation responses are mediated by sugar signaling in Arabidopsis. Planta 225, 907-918.

Karthikeyan, A. S., Varadarajan, D. K., Mukatira, U. T., D’Urzo, M. P., Damsz, B., and Raghothama, K. G. (2002). Regulated expression of Arabidopsis phosphate transporters. Plant Physiol. 130, 221-233.

Kobae, Y., and Hata, S. (2010). Dynamics of periarbuscular membranes visualized with a fluorescent phosphate transporter in arbuscular mycorrhizal roots of rice. Plant Cell Physiol. 51, 341-353.

Koyama, T., Ono, T., Shimizu, M., Jinbo, T., Mizuno, R., Tomita, K., Mitsukawa, N., Kawazu, T., Kimura, T., Ohmiya, K., and Sakka, K. (2005). Promoter of Arabidopsis thaliana phosphate transporter gene drives root-specific expression of transgene in rice. J. Biosci. Bioeng. 99, 38-42.

Lagerstedt, J. O., Zvyagilskaya, R., Pratt, J. R., Pattison-Granberg, J., Kruckeberg, A. L., Berden, J. A., and Persson, B. L. (2002). Mutagenic and functional analysis of the C-terminus of Saccharomyces cerevisiae Pho84 phosphate transporter. FEBS Lett. 526, 31-37.

Lee, D. A., Chen, A., and Schroeder, J. I. (2003). Ars1, an Arabidopsis mutant exhibiting increased tolerance to arsenate and increased phosphate uptake. Plant J. 35, 637-646.

Lefebvre, D. D., Duff, S. M., Fife, C. A. Julien-Inalsingh, C., and Plaxton, W. C. (1990). Response to phosphate deprivation in Brassica nigra suspension cells: enhancement of intracellular, cell surface, and secreted phosphatase activities compared to increases in pi-absorption rate. Plant Physiol. 93, 504-511.

Leggewie, G., Willmitzer, L., and Riesmeier, J. W. (1997). Two cDNAs from potato are able to complement a phosphate uptake-deficient yeast mutant: identification of phosphate transporters from higher plants. Plant Cell 9, 381-392.

Lei, M., Liu, Y., Zhang, B., Zhao, Y., Wang, X., Zhou, Y., Raghothama, K. G., and Liu, D. (2011). Genetic and genomic evidence that sucrose is a global regulator of plant response to phosphate starvation in Arabidopsis. Plant Physiol. 156, 1116-1130.

Liu, C., Muchhal, U. S., Uthappa, M., Kononowicz, A. K., and Raghothama, K. G. (1998a). Tomato phosphate transporter genes are differentially regulated in plant tissues by phosphorus. Plant Physiol. 116, 91-99. 
Liu, H., Trieu, A. T., Blaylock, L. A., and Harrison, M. J. (1998b). Cloning and characterization of two phosphate transporters from Medicago truncatula roots: regulation in response to phosphate and to colonization by arbuscular mycorrhizal (AM) fungi. Mol. Plant Microbe Interact. $11,14-22$.

Liu, J., Uhde-Stone, C., Li, A., Vance, C., and Allan, D. (2001). A phosphate transporter with enhanced expression on proteoid roots of white lupin (Lupinus albus L.). Plant Soil 237, 257-266.

Liu, J., Versaw, W. K., Pumplin, N., Gomez, S. K., Blaylock, L. A., and Harrison, M. J. (2008). Closely related members of the Medicago truncatula PHT1 phosphate transporter gene family encode phosphate transporters with distinct biochemical activities. J. Biol. Chem. 283, 24673-24681.

Loque, D., Lalonde, S., Looger, L. L., von Wiren, N., and Frommer, W. B. (2007). A cytosolic trans-activation domain essential for ammonium uptake. Nature 446, 195-198.

Loth-Pereda, V., Orsini, E., Courty, P. E., Lota, F., Kohler, A., Diss, L., Blaudez, D., Chalot, M., Nehls, U., Bucher, M., and Martin, F. (2011). Structure and expression profile of the phosphate Pht1 transporter gene family in mycorrhizal Populus trichocarpa. Plant Physiol. 156, 2141-2154.

Ludewig, U., Wilken, S., Wu, B., Jost, W., Obrdlik, P., El Bakkoury, M., Marini, A. M., Andre, B., Hamacher, T., Boles, E., von Wiren, N., and Frommer, W. B. (2003). Homo- and hetero-oligomerization of ammonium transporter-1 NH4 uniporters. J. Biol. Chem. 278, 45603-45610.

Lundh, F., Mouillon, J. M., Samyn, D., Stadler, K., Popova, Y., Lagerstedt, J. O., Thevelein, J. M., and Persson, B. L. (2009). Molecular mechanisms controlling phosphateinduced downregulation of the yeast Pho84 phosphate transporter. Biochemistry 48, 4497-4505.

Ming, F., Mi, G. H., Lu, Q., Yin, S., Zhang, S. S., Guo, B., and Shen, D. L. (2005). Cloning and characterization of cDNA for the Oryza sativa phosphate transporter. Cell. Mol. Biol. Lett. 10, 401-411.

Misson, J., Raghothama, K. G., Jain, A., Jouhet, J., Block, M. A., Bligny, R., Ortet, P., Creff, A., Somerville, S., Rolland, N., Doumas, P., Nacry, P., Herrerra-Estrella, L., Nussaume, L., and Thibaud, M. C. (2005). A genome-wide transcriptional analysis using Arabidopsis thaliana affymetrix gene chips determined plant responses to phosphate deprivation. Proc. Natl. Acad. Sci. U.S.A. 102, 11934-11939.

Misson, J., Thibaud, M. C., Bechtold, N., Raghothama, K., and Nussaume, L. (2004). Transcriptional regulation and functional properties of Arabidopsis Pht1;4, a high affinity transporter contributing greatly to phosphate uptake in phosphate deprived plants. Plant Mol. Biol. 55, 727-741.

Mitsukawa, N., Okumura, S., Shirano, Y., Sato, S., Kato, T., Harashima, S., and Shibata, D. (1997). Overexpression of an Arabidopsis thaliana highaffinity phosphate transporter gene in tobacco cultured cells enhances cell growth under phosphate-limited conditions. Proc. Natl. Acad. Sci. U.S.A. 94, 7098-7102.

Morcuende, R., Bari, R., Gibon, Y., Zheng, W., Pant, B. D., Blasing, O., Usadel, B., Czechowski, T., Udvardi, M. K., Stitt, M., and Scheible, W. R. (2007). Genome-wide reprogramming of metabolism and regulatory networks of Arabidopsis in response to phosphorus. Plant Cell Environ. 30, 85-112.

Muchhal, U. S., Pardo, J. M., and Raghothama, K. G. (1996). Phosphate transporters from the higher plant Arabidopsis thaliana. Proc. Natl. Acad. Sci. U.S.A. 93, 10519-10523.

Muchhal, U. S., and Raghothama, K. G. (1999). Transcriptional regulation of plant phosphate transporters. Proc. Natl. Acad. Sci. U.S.A. 96, 5868-5872.

Mudge, S. R., Rae, A. L., Diatloff, E., and Smith, F. W. (2002). Expression analysis suggests novel roles for members of the Pht 1 family of phosphate transporters in Arabidopsis. Plant J. 31, 341-353.

Mukatira, U. T., Liu, C., Varadarajan, D. K., and Raghothama, K. G. (2001). Negative regulation of phosphate starvation-induced genes. Plant Physiol. 127, 1854-1862. Nagarajan, V. K., Jain, A., Poling, M. D., Lewis, A. J., Raghothama, K. G., and Smith, A. P. (2011). Arabidopsis Pht1;5 mobilizes phosphate between source and sink organs, and influences the interaction between phosphate homeostasis and ethylene signaling. Plant Physiol. 156, 1149-1163.

Nagy, R., Karandashov, V., Chague, V., Kalinkevich, K., Tamasloukht, M., Xu, G., Jakobsen, I., Levy, A. A., Amrhein, N., and Bucher, M. (2005). The characterization of novel mycorrhiza-specific phosphate transporters from Lycopersicon esculentum and Solanum tuberosum uncovers functional redundancy in symbiotic phosphate transport in solanaceous species. Plant J. 42, 236-250.

Nagy, R., Vasconcelos, M. J., Zhao, S., Mcelver, J., Bruce, W., Amrhein, N., Raghothama, K. G., and Bucher, M. (2006). Differential regulation of five Phtl phosphate transporters from maize (Zea mays L.). Plant Biol. (Stuttg.) 8, 186-197.

Nakamori, K., Takabatake, R., Umehara, Y., Kouchi, H., Izui, K., and Hata, S. (2002). Cloning, functional expression, and mutational analysis of a cDNA for Lotus japonicus mitochondrial phosphate transporter. Plant Cell Physiol. 43, 1250-1253.

Nilsson, L., Muller, R., and Nielsen, T. H. (2007). Increased expression of the MYB-related transcription factor, PHR1, leads to enhanced phosphate uptake in Arabidopsis thaliana. Plant Cell Environ. 30, 1499-1512.

Nuhse, T. S., Stensballe, A., Jensen, O. N. and Peck, S. C. (2004). Phosphoproteomics of the Arabidopsis plasma membrane and a new phosphorylation site database. Plant Cell 16 2394-2405.

Okumura, S., Mitsukawa, N., Shirano, Y., and Shibata, D. (1998). Phosphate transporter gene family of Arabidopsis thaliana. DNA Res. 5, 261-269.

Othman, I., and Al-Masri, M. S. (2007). Impact of phosphate industry on the environment: a case study. Appl. Radiat. Isot. 65, 131-141.

Paszkowski, U., Kroken, S., Roux, C. and Briggs, S. P. (2002). Rice phosphate transporters include an evolutionarily divergent gene specifically activated in arbuscular mycorrhizal symbiosis. Proc. Natl. Acad. Sci. U.S.A. 99, 13324-13329.

Persson, B. L., Lagerstedt, J. O., Pratt, J. R., Pattison-Granberg, J., Lundh, K., Shokrollahzadeh, S., and Lundh, F. (2003). Regulation of phosphate acquisition in Saccharomyces cerevisiae. Curr. Genet. 43, 225-244.

Poirier, Y., and Bucher, M. (2002). "Phosphate transport and homeostasis in Arabidopsis," in The Arabidopsis Book, eds C. R. Somerville and E. M. Meyerowitz (Rockville, MD: American Society of Plant Biologists), 1-35.

Poirier, Y., Thoma, S., Somerville, C., and Schiefelbein, J. (1991). Mutant of Arabidopsis deficient in xylem loading of phosphate. Plant Physiol. 97, 1087-1093.

Prak, S., Hem, S., Boudet, J., Viennois, G., Sommerer, N., Rossignol, M., Maurel, C., and Santoni, V. (2008). Multiple phosphorylations in the Cterminal tail of plant plasma membrane aquaporins: role in subcellular trafficking of AtPIP2;1 in response to salt stress. Mol. Cell. Proteomics 7, 1019-1030.

Preuss, C. P., Huang, C. Y., and Tyerman, S. D. (2011). Proton-coupled high-affinity phosphate transport revealed from heterologous characterization in Xenopus of barleyroot plasma membrane transporter, HvPHT1;1. Plant Cell Environ. 34, 681-689.

Pumplin, N., and Harrison, M. J. (2009). Live-cell imaging reveals periarbuscular membrane domains and organelle location in Medicago truncatula roots during arbuscular mycorrhizal symbiosis. Plant Physiol. 151, 809-819.

Rae, A. L., Cybinski, D. H., Jarmey, J. M., and Smith, F. W. (2003). Characterization of two phosphate transporters from barley; evidence for diverse function and kinetic properties among members of the Phtl family. Plant Mol. Biol. 53, 27-36.

Raghothama, K. G. (1999). Phosphate acquisition. Annu. Rev. Plant Physiol. Plant Mol. Biol. 50, 665-693.

Rausch, C., and Bucher, M. (2002). Molecular mechanisms of phosphate transport in plants. Planta 216, 23-37.

Richardson, A. E. (1994). "Soil microorganisms and phosphorus availability," in Soil Biota: Management in Sustainable Farming Systems, eds C. E. Pankhurst, B. M. Doube, V. V. S. R. Gupta, and P. R. Grace, 50-62.

Rouached, H., Stefanovic, A., Secco, D., BulakArpat, A., Gout, E., Bligny, R., and Poirier, Y. (2011). Uncoupling phosphate deficiency from its major effects on growth and transcriptome via $\mathrm{PHO}$ expression in Arabidopsis. Plant J. 65, 557-570.

Rubio, V., Linhares, F., Solano, R., Martin, A. C., Iglesias, J., Leyva, A., and Paz-Ares, J. (2001). A conserved MYB transcription factor involved in phosphate starvation signaling both in vascular plants and in unicellular algae. Genes Dev. 15, 2122-2133.

Sakano, K. (1990). Proton/phosphate stoichiometry in uptake of inorganic phosphate by cultured cells of Catharanthus roseus (L.) G. Don. Plant Physiol. 93, 479-483.

Schachtman, D. P., Reid, R. J., and Ayling, S. M. (1998). Phosphorus uptake by plants: from soil to cell. Plant Physiol. 116, 447-453.

Schunmann, P. H., Richardson, A. E., Smith, F. W., and Delhaize, E. (2004a). Characterization of promoter expression patterns derived from the Phtl phosphate transporter genes of barley (Hordeum vulgare L.). J. Exp. Bot. 55, 855-865. 
Schunmann, P. H., Richardson, A. E., Vickers, C. E., and Delhaize, E. (2004b). Promoter analysis of the barley Pht1;1 phosphate transporter gene identifies regions controlling root expression and responsiveness to phosphate deprivation. Plant Physiol. 136, 4205-4214.

Shimogawara, K., and Usuda, H. (1995). Uptake of inorganic phosphate by suspension-cultured tobacco cells: kinetics and regulation by $\mathrm{Pi}$ starvation. Plant Cell Physiol. 36, 341-351.

Shin, H., Shin, H. S., Dewbre, G. R., and Harrison, M. J. (2004). Phosphate transport in Arabidopsis: Pht1;1 and Pht 1;4 play a major role in phosphate acquisition from both lowand high-phosphate environments. Plant J. 39, 629-642.

Smith, A. P., Jain, A., Deal, R. B., Nagarajan, V. K., Poling, M. D., Raghothama, K. G., and Meagher, R. B. (2010). Histone H2A.Z regulates the expression of several classes of phosphate starvation response genes but not as a transcriptional activator. Plant Physiol. 152, 217-225.

Smith, F. W., Cybinski, D. H., and Rae, A. L. (eds). (1999). Regulations of Expression of Genes Encoding Phosphate Transporters in Barley Roots. Dordrecht: Kluwer Academic Publishers.

Smith, F. W., Ealing, P. M., Dong, B., and Delhaize, E. (1997). The cloning of two Arabidopsis genes belonging to a phosphate transporter family. Plant J. 11, 83-92.

Smith, F. W., Rae, A. L., and Hawkesford, M. J. (2000). Molecular mechanisms of phosphate and sulphate transport in plants. Biochim. Biophys. Acta 1465, 236-245.

Smith, S. E., and Barker, S. J. (2002). Plant phosphate transporter genes help harness the nutritional benefits of arbuscular mycorrhizal symbiosis. Trends Plant Sci. 7, 189-190.

Smith, S. E., and Read, D. J. (1997). Mycorrhizal Symbiosis, 2nd Edn. San Diego, CA: Academic Press.

Stefanovic, A., Arpat, A. B., Bligny, R., Gout, E., Vidoudez, C., Bensimon,
M., and Poirier, Y. (2011). Overexpression of $\mathrm{PHO}$ in Arabidopsis leaves reveals its role in mediating phosphate efflux. Plant J. 66, 689-699.

Takano, J., Miwa, K., Yuan, L. X., Von Wiren, N., and Fujiwara, T. (2005). Endocytosis and degradation of BOR1, a boron transporter of Arabidopsis thaliana, regulated by boron availability. Proc. Natl. Acad. Sci. U.S.A. 102, 12276-12281.

Thibaud, M. C., Arrighi, J. F., Bayle, V., Chiarenza, S., Creff, A., Bustos, R., Paz-Ares, J., Poirier, Y., and Nussaume, L. (2010). Dissection of local and systemic transcriptional responses to phosphate starvation in Arabidopsis. Plant J. 64, 775-789.

Ticconi, C. A., Delatorre, C. A., and Abel, S. (2001). Attenuation of phosphate starvation responses by phosphite in Arabidopsis. Plant Physiol. 127, 963-972.

Tittarelli, A., Milla, L., Vargas, F., Morales, A., Neupert, C., Meisel, L. A., Salvo, G. H., Penaloza, E., Munoz, G., Corcuera, L. J., and Silva, H. (2007). Isolation and comparative analysis of the wheat TaPT2 promoter: identification in silico of new putative regulatory motifs conserved between monocots and dicots. J. Exp. Bot. 58, 2573-2582.

Ullrich, C. I., and Novacky, A. J. (1990). Extra- and intracellular pH and membrane potential changes induced by $\mathrm{K}, \mathrm{Cl}, \mathrm{H}(2) \mathrm{PO}(4)$, and $\mathrm{NO}(3)$ uptake and fusicoccin in root hairs of Limnobium stoloniferum. Plant Physiol. 94, 1561-1567.

Ullrich-Eberius, C. I., Novacky, A., Fischer, E., and Luttge, U. (1981). Relationship between energy-dependent phosphate uptake and the electrical membrane potential in Lemna gibba G1. Plant Physiol. 67, 797-801.

Ullrich-Eberius, C. I., Novacky, A., and Van Bel, A. J. E. (1984). Phosphate uptake in Lemna gibba G1: energetics and kinetics. Planta 161, 46-52.

Vance, C. P., Uhde-Stone, C., and Allan, D. (2003). Phosphorus acquisition and use: critical adaptations by plants for securing a nonrenewable resource. New Phytol. 157, 423-447.
Varadarajan, D. K., Karthikeyan, A. S. Matilda, P. D., and Raghothama, K. G. (2002). Phosphite, an analog of phosphate, suppresses the coordinated expression of genes under phosphate starvation. Plant Physiol. 129, 1232-1240.

Versaw, W. K. (1995). A phosphaterepressible, high-affinity phosphate permease is encoded by the pho-5+ gene of Neurospora crassa. Gene 153, 135-139.

Versaw, W. K., and Metzenberg, R. L. (1995). Repressible cationphosphate symporters in Neurospora crassa. Proc. Natl. Acad. Sci. U.S.A. 92, 3884-3887.

Von Vexhull, H. R., and Mutert, E. (1998). "Global extent, development and economic impact of acid soils," in Plant-Soil Interactions at Low $\mathrm{pH}$ : Principles and Management, eds $\mathrm{R}$. A. Date, N. J. Grundon, G. E. Rayment, and M. E. Probert (Dordrecht: Kluwer), 5-19.

Winter, D., Vinegar, B., Nahal, H., Ammar, R., Wilson, G. V., and Provart, N. J. (2007). An "electronic fluorescent pictograph" browser for exploring and analyzing largescale biological data sets. PLoS ONE 2, e718. doi:10.1371/journal.pone.0000718

Wirth, J., Chopin, F., Santoni, V., Viennois, G., Tillard, P., Krapp, A., Lejay, L., Daniel-Vedele, F., and Gojon, A. (2007). Regulation of root nitrate uptake at the NRT2.1 protein level in Arabidopsis thaliana. J. Biol. Chem. 32, 23541-23552.

Wu, P., Ma, L., Hou, X., Wang, M., Wu, Y., Liu, F., and Deng, X. W. (2003). Phosphate starvation triggers distinct alterations of genome expression in Arabidopsis roots and leaves. Plant Physiol. 132, 1260-1271.

Wu, Z., Ren, H., McGrath, S. P., Wu, P. and Zhao, F.-J. (2011). Investigating the contribution of the phosphate transport pathway to arsenic accumulation in rice. Plant Physiol. 157, 498-508.

Wykoff, D. D., Grossman, A. R., Weeks, D. P., Usuda, H., and Shimogawara, K. (1999). Psrl, a nuclear localized protein that regulates phosphorus metabolism in Chlamydomonas. Proc. Natl. Acad. Sci. U.S.A. 96, 15336-15341.

Xiao, K., Liu, J., Dewbre, G., Harrison, M., and Wang, Z. Y. (2006). Isolation and characterization of root-specific phosphate transporter promoters from Medicago truncatula. Plant Biol. (Stuttg.) 8, 439-449.

$\mathrm{Xu}$, G. H., Chague, V., MelamedBessudo, C., Kapulnik, Y., Jain, A., Raghothama, K. G., Levy, A. A., and Silber, A. (2007). Functional characterization of LePT4: a phosphate transporter in tomato with mycorrhiza-enhanced expression. $J$. Exp. Bot. 58, 2491-2501.

Zhou, J., Jiao, F., Wu, Z., Li, Y., Wang, X., He, X., Zhong, W., and Wu, P. (2008). OsPHR2 is involved in phosphate-starvation signaling and excessive phosphate accumulation in shoots of plants. Plant Physiol. 146, 1673-1686.

Conflict of Interest Statement: The authors declare that the research was conducted in the absence of any commercial or financial relationships that could be construed as a potential conflict of interest.

Received: 10 August 2011; accepted: 03 November 2011; published online: 30 November 2011.

Citation: Nussaume L, Kanno S, Javot H, Marin E, Pochon N, Ayadi A, Nakanishi TM and Thibaud M-C (2011) Phosphate import in plants: focus on the PHT1 transporters. Front. Plant Sci. 2:83. doi: 10.3389/fpls.2011.00083

This article was submitted to Frontiers in Plant Traffic and Transport, a specialty of Frontiers in Plant Science.

Copyright (c) 2011 Nussaume, Kanno, Javot, Marin, Pochon, Ayadi, Nakanishi and Thibaud. This is an open-access article subject to a non-exclusive license between the authors and Frontiers Media $S A$, which permits use, distribution and reproduction in other forums, provided the original authors and source are credited and other Frontiers conditions are complied with. 